\title{
Effects of changing land use in the Netherlands on net carbon fixation
}

\author{
J. WOLF ${ }^{1} \&$ L. H. J. M. JANSSEN ${ }^{2}$ \\ ${ }^{1}$ Department of Theoretical Production Ecology, Wageningen Agricultural University, P.O. \\ Box 430, NL 6700 AK Wageningen, Netherlands. \\ ${ }^{2}$ Ministry of Housing, Physical planning and Environment, Directorate-general Environ- \\ ment, Directorate Air, Section Climate, P.O. Box 450, NL 2260 MB Leidschendam, \\ Netherlands.
}

Received 10 March 1991; accepted 3 July 1991

\begin{abstract}
For three land use systems, arable land, grassland and forest, average carbon flows and carbon pools in the Netherlands have been determined. For harvested products data are available from statistics and they were used as a basis for calculating the carbon flows. Average carbon pools, particularly in the soil, cannot be derived directly. For the calculation of this carbon pool a method has been applied that requires only three input data: the average amount of crop or tree residues, the decomposition rate of soil organic matter and the socalled humification coefficient. For broad studies this simple method can particularly be useful. However, this method can only be applied to situations in equilibrium, where the rates of incorporation of crop residues or tree litter and decomposition of soil organic matter are just equal and hence, the soil carbon is constant. In the soil, a state of equilibrium may not really occur, as continually changes in crop rotation and land use will take place. For a changing land use and hence a changing rate of incorporation of organic material it is shown how the new state of equilibrium and the rate of change in carbon pool size can be calculated. For a number of actual changes in land use in the Netherlands the resulting changes in carbon pool sizes were determined.
\end{abstract}

Keywords: carbon fixation, changing land use, $\mathrm{CO}_{2}$ emission, Netherlands, soil organic matter

\section{Introduction}

Atmospheric $\mathrm{CO}_{2}$ transmits solar radiation to the surface of the earth, but it partly intercepts the radiation emitted by the earth surface. Therefore, increasing concentrations of this and other 'greenhouse' gases such as $\mathrm{CH}_{4}, \mathrm{~N}_{2} \mathrm{O}, \mathrm{O}_{3}$ and CFCs, might induce a rise of the average temperature at the earth surface. The relative contribution of $\mathrm{CO}_{2}$ to this expected global warming is about $50 \%$ (Bouwman, 1990).

Rise of the atmospheric $\mathrm{CO}_{2}$ content is mainly due to the increasing combustion of fossil fuels, but release of $\mathrm{CO}_{2}$ from soils and vegetation may also play a role. If 
for various land use systems information on carbon flows and carbon pools is available, this information can be used to calculate the changes in carbon pool size in case of changed land use or crop rotation. Changing land use that results in an increase in carbon pool size, may help to reduce the effect of fossil fuel combustion on rising atmospheric $\mathrm{CO}_{2}$.

\section{Equilibrium approach}

For three land use systems, arable land, grassland and forest, carbon flows and pools have been determined for their total areas in the Netherlands around 1987. From these data the average carbon flows and carbon pools per hectare have been derived (Figure 1). For harvested products data are available from Dutch statistics on agriculture and forestry and they form the basis for calculating the carbon flows. The average carbon pools, particularly that in the soil, cannot be derived directly. Only the carbon pool in standing wood is known. To derive the amount of soil carbon the following approach has been applied.

For each arable crop the average amount of crop residues that remains in the field after harvest is known. From these amounts of residues and the relative areas per crop species in 1987 the average amount of crop residues can be derived for arable cropping. For various crops data are available on the fraction of the residues

A

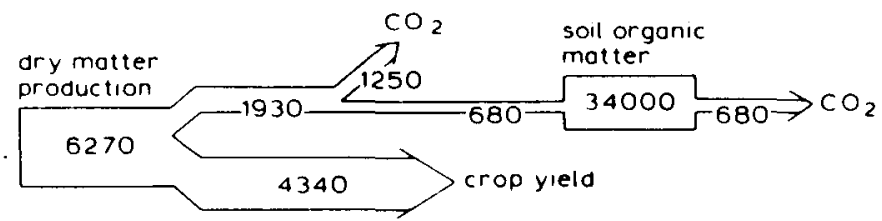

B.
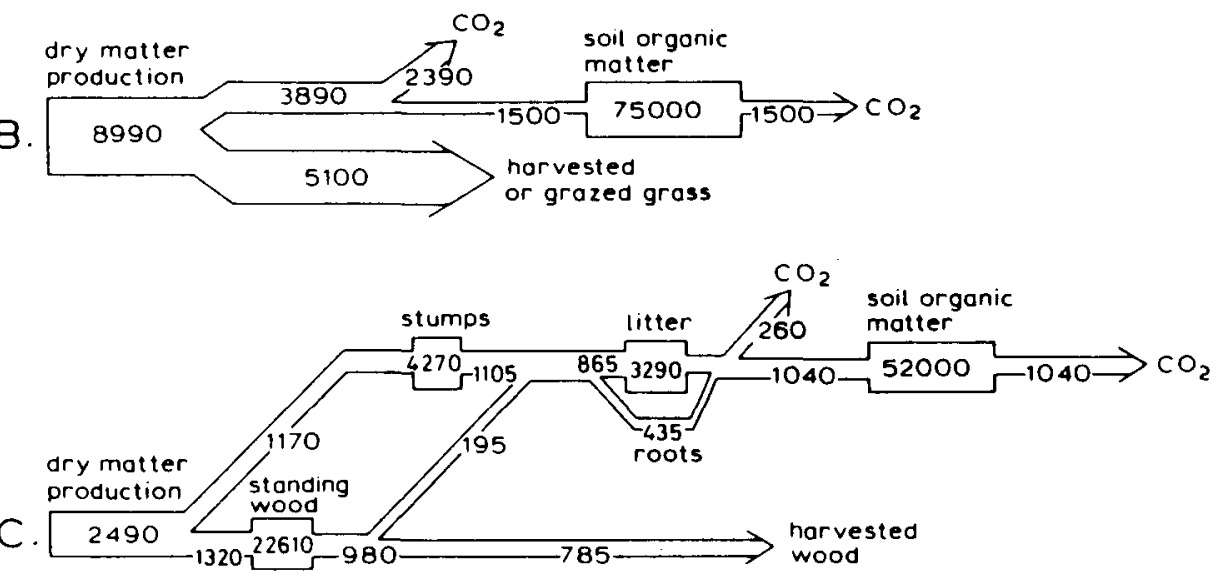

Fig. 1: Average carbon flows $\left(\mathrm{kg} \mathrm{C} \mathrm{ha}^{-1} \mathrm{yr}^{-1}\right)$ and carbon pools $\left(\mathrm{kg} \mathrm{C} \mathrm{ha}^{-1}\right)$ in land use systems in the Netherlands in 1987. A: arable land; B: grassland; C: forest. 
which remains after a period of one year in the soil (Table 1). This fraction is also called humification coefficient. This coefficient allows calculation of the amount of organic material that is not decomposed during a period of one year and is indicated as 'effective supply of organic material'. On average the effective supply for arable cropping is found to be 0.35 times the amount of crop residues (Figure 1a).

The amount of soil organic matter can be calculated, if the effective supply of organic material and the annually decomposed fraction of soil organic matter are known. Decomposition of organic matter in Dutch soils has been studied extensively by Kortleven (1963). On average, organic matter in arable land has been found to decompose at a rate of $2 \%$ per year. For a state of equilibrium where the effective supply and the rate of decomposition are just equal and the pool of soil organic matter is constant, this pool can be calculated as $50(=1 / 0.02)$ times the effective supply (Figure 1).

This simple equilibrium approach has its limitations. In addition to the calculated pool of 'active' soil organic matter, also soil organic matter may be present that practically is not involved in decomposition processes. This inert organic matter consists of peat residues, humus coal in sandy soils, strongly fixed organic matter in clay soils, etc. As it decomposes at a very low rate it can be neglected in this approach.

For the Netherlands one average value for the relative decomposition rate of soil organic matter is used. This rate increases somewhat with average temperature (Jenkinson \& Ayanaba, 1977), with soil-pH (Janssen et al., 1990) and with soil drainage, and decreases with higher carbon-nitrogen ratio and clay content (Jenkinson, 1988). In such situations the soil organic matter pools at equilibrium will differ from the pool sizes calculated for average conditions in the Netherlands.

A state of equilibrium may not really occur, as continually changes in crop rotation, fertilizer and manure application, and land use will take place. The actual course of accumulation and decomposition of soil organic matter might be calculated with the method of Janssen (1984), but that would require complete informa-

Table 1. Remaining fraction of various crop and tree residues after a period of one year in the soil (humification coefficient). Based on data of Kolenbrander (1974).

\begin{tabular}{lll}
\hline Residues & \multicolumn{2}{l}{ Humification coefficient expressed in } \\
\cline { 2 - 3 } & dry organic material & carbon \\
& & \\
Green material & 0.20 & 0.26 \\
Grass & 0.30 & 0.39 \\
Straw & 0.30 & 0.39 \\
Roots & 0.35 & 0.45 \\
Manure & 0.50 & 0.58 \\
Litter of deciduous trees & 0.57 & 0.69 \\
Litter of coniferous trees & 0.72 & 0.87
\end{tabular}

${ }_{1}^{1}$ Carbon concentrations in crop residues, tree litter, manure and soil organic matter are on an average $0.45,0.48,0.50$ and 0.58 , respectively. 
tion on the initial pool of soil organic matter and on the time course of crop cultivation and manuring. For broad studies such information is generally not available and in that case the proposed approach can be usable. Changes in land use and crop rotation affect the state of equilibrium. The way in which this can be handled, is treated next.

\section{Application of the equilibrium approach}

Changes in crop rotation, manure application, etc. result in a changed effective supply of organic material. At an increasing effective supply the pool of soil organic matter will increase too. To derive the rate of change in pool size, the simple method for calculating accumulation and depletion of soil organic matter by Kortleven (1963) is used. If the relative decomposition rate of organic matter is $0.02 \mathrm{yr}^{-1}$ and the effective supply or organic material increases with 10 units, the accumulation of the soil organic matter can be calculated via: $10 / 0.02 \times\left(1-(1-0.02)^{t}\right)$, where $t$ is time. In this example the pool of soil organic matter will become 500 units larger at the new state of equilibrium. After 50,100 and 150 year 64,87 and $95 \%$, respectively of this maximum change in pool size has taken place. If the effective supply of organic material decreases to the same extent, the depletion of the soil organic matter pool can be calculated in exactly the same way. Further approach of the pool size at equilibrium occurs at a continually decreasing rate with time. Therefore, a period of 100 years, or in general terms twice the average residence time in the pool of soil organic matter, is chosen as a somewhat arbitrary measure for the time period, in which a new state of equilibrium will be attained for the greater part.

In the equation for calculating the accumulation and depletion of soil organic matter, the relative decomposition rate has a fixed value. In reality the relative decomposition rate of organic matter is much higher than $0.02 \mathrm{yr}^{-1}$ during the first years after application and with time it decreases to values lower than 0.02 . This decreasing rate has also been found by Kolenbrander (1974) for various organic materials and is caused by the heterogeneous composition of organic material. Easily decomposible material is decomposed first and is partly resynthesized into more stable products and hence, organic material becomes gradually more resistent (Minderman, 1968). As a consequence, a large increase (decrease) in effective supply of organic material will result in less accumulation (depletion) of the soil organic matter pool during the first years than calculated with the applied equation. As this will be made good in the long run, this effect can be neglected.

Over the last twenty years the relative areas of cultivated arable crops in the Netherlands have changed considerably. From 1970 till 1987 the cultivated area of small grains was halved and in the same period the area of fodder maize increased from zero to one fourth of the total area of arable land (Table 2). As the cultivation of fodder maize yields much less crop residues than that of small grains, the average effective supply of organic material became less and consequently the pool of active soil organic matter decreased from $47150 \mathrm{~kg} \mathrm{Cha}^{-1}$ in 1970 to $33950 \mathrm{~kg} \mathrm{Cha}^{-1}$ in 1987. As it takes about 100 years before the new state of equilibrium is attained, the average rate of decrease in active soil organic matter will be $132 \mathrm{~kg} \mathrm{C} \mathrm{ha}^{-1} \mathrm{yr}^{-1}$. 
Table 2. Effective supplies of organic material calculated for arable land with average crop rotations as found in the specified years in the Netherlands.

\begin{tabular}{|c|c|c|c|c|c|c|}
\hline \multirow[t]{3}{*}{ Crop } & \multicolumn{2}{|c|}{ Relative area } & \multirow{3}{*}{$\begin{array}{l}\text { Crop residues } \\
\left(\mathrm{kg} \mathrm{Cha}^{-1} \mathrm{yr}^{-1}\right)\end{array}$} & \multirow{3}{*}{$\begin{array}{l}\text { Humification } \\
\text { coefficient } \\
\left(\mathrm{kg} \mathrm{C} \mathrm{kg}^{-1} \mathrm{C}\right)\end{array}$} & \multirow{2}{*}{\multicolumn{2}{|c|}{$\begin{array}{l}\text { Effective supply of } \\
\text { organic material per crop } \\
\left(\mathrm{kgCha}^{-1} \mathrm{yr}^{-1}\right)\end{array}$}} \\
\hline & \multirow[t]{2}{*}{1970} & \multirow[t]{2}{*}{1987} & & & & \\
\hline & & & & & 1970 & 1987 \\
\hline \multirow{2}{*}{$\begin{array}{l}\text { Small grains } \\
\text { Tuber- and } \\
\text { rootcrops }\end{array}$} & 0.52 & 0.23 & 3270 & 0.40 & 680 & 301 \\
\hline & 039 & 039 & 2070 & & 226 & 226 \\
\hline Maize & 0.00 & 0.26 & 900 & $\begin{array}{l}0.20 \\
0.44\end{array}$ & $\begin{array}{r}220 \\
0\end{array}$ & $\begin{array}{l}220 \\
103\end{array}$ \\
\hline Other & 0.09 & 0.12 & 1130 & 0.36 & 37 & 49 \\
\hline Total & 1.00 & 1.00 & & & 943 & 679 \\
\hline
\end{tabular}

${ }^{1}$ It is taken into account that $40 \%$ of straw and $10 \%$ of beet residues are actually not left in the field.

\section{Changes in land use and manuring}

\section{Grasslands}

Agricultural statistics only give coarse data on the total amounts of grass grazed and mown in 1986 in the Netherlands. From these amounts the total dry matter production and the root and stubble residues can be derived, if the conservation losses and the fraction partitioned to root and stubble residues are known. This fraction is for harvested grassland about $40 \%$ of the total dry matter production and for grazed pastures about $47 \%$ because of grazing losses. If also conservation losses $5 \%$ for dried grass meal and $20 \%$ for hay and silage, are taken into account, an average dry matter production of $8990 \mathrm{~kg} \mathrm{Cha}^{-1} \mathrm{yr}^{-1}$ is found for Dutch grassland. From this amount $5100 \mathrm{~kg} \mathrm{C} \mathrm{ha}^{-1} \mathrm{yr}^{-1}$ is harvested or grazed and $3890 \mathrm{~kg} \mathrm{Cha}^{-1} \mathrm{yr}^{-1}$ is left in the field. These residues are incorporated into the soil and after one year they result in an effective supply of organic material of $1500 \mathrm{~kg} \mathrm{Cha}^{-1} \mathrm{yr}^{-1}$ (Figure $1 \mathrm{~b}$ ). For the calculation of the pool of soil organic matter an identical value for the relative decomposition rate is used as previously for arable land, i.e. $2 \% \mathrm{yr}^{-1}$. At a state of equilibrium this yields a pool of $75000 \mathrm{~kg} \mathrm{Cha}^{-1}$.

Since 1970 fodder maize has become increasingly of importance for the roughage supply of cattle. From 1970 to 1987 the area cultivated with fodder maize has changed from nil to 200000 ha, and at the same time the grassland area decreased by $200000 \mathrm{ha}$. If grassland is converted into arable land, the pool of soil organic matter decreases by about $41000 \mathrm{~kg} \mathrm{Cha}^{-1}$ (Figure 1b) till a new state of equilibrium is largely attained in about 100 years.

Also in studies by Hoogerkamp (1973) for the Netherlands, by van Hove (1969) for Belgium and by Jenkinson (1988) for England, the amount of soil organic matter in grasslands is found to be much larger than in arable lands (Table 3). The amounts of root and stubble residues produced on grassland are much larger than those produced on arable land and this may explain the larger amount of soil organic matter in grasslands (Figure 1). The ratio between the calculated pools of soil or- 
Table 3. Average amounts of organic matter and of carbon ${ }^{1}$ in top soils $(0-30 \mathrm{~cm}$; litter layer included) in Belgium for different forms of land use. Based on data of van Hove (1969).

\begin{tabular}{lll}
\hline Land use system & $\begin{array}{l}\text { Organic matter } \\
\left(10^{3} \mathrm{~kg} \mathrm{ha}^{-1}\right)\end{array}$ & $\begin{array}{l}\text { Carbon } \\
\left(10^{3} \mathrm{~kg} \mathrm{C} \mathrm{ha}^{-1}\right)\end{array}$ \\
Arable land & 88 & 51 \\
Grassland & 132 & 77 \\
Coniferous forest & 113 & 66 \\
Deciduous forest & 152 & 88 \\
\hline
\end{tabular}

Carbon concentration in soil organic matter is set at 0.58 .

ganic matter in grassland and in arable land with an average crop rotation as found until 1970 (Table 2), is about identical to the actual ratio between the average amounts of soil organic matter in grassland and in arable land in Belgium in the sixties (Table 3). In the calculated pools, however, inert organic matter and the effect of manuring are not taken into account. These ratios give no indication that for grasslands a different value for the relative decomposition rate should be used, although soil tillage on arable land is often assumed to enlarge the soil aeration and by that the relative decomposition rate.

\section{Forests}

Carbon flows and pools in forests can only be derived indirectly. This is due to the fact that for forests in the Netherlands only the amount of harvested wood and the amount of standing wood are known from statistics. However, the amount of harvested wood is not identical to the wood growth and in addition, for total dry matter and litter production no data are available.

The amount of standing wood in the Netherlands was in 1985 on average $94.2 \mathrm{~m}^{3}$ $\mathrm{ha}^{-1}$ or $22610 \mathrm{~kg} \mathrm{Cha}^{-1}$ and the average amount of annually harvested wood (bark included) in the period 1975-1986 was $3.27 \mathrm{~m}^{3} \mathrm{ha}^{-1} \mathrm{yr}^{-1}$ or $785 \mathrm{~kg} \mathrm{Cha}^{-1} \mathrm{yr}^{-1}$ (FAO, 1988). Total wood growth has not been determined, but this rate can be derived from areas per tree type in the Netherlands and estimates for the annual wood growth per hectare dominated by that tree type. In this way an average wood growth is calculated of $5.86 \mathrm{~m}^{3} \mathrm{ha}^{-1} \mathrm{yr}^{-1}$ or $1405 \mathrm{~kg} \mathrm{Cha}^{-1} \mathrm{yr}^{-1}$ (bark included). That is about twice the amount of harvested wood. As according to statistics about half the forest area has as main objective nature and landscape conservation, it is assumed that only in half the forest area, mainly used for wood production, the production is that high and that in the other forest areas the wood production is only half that amount. That results in a more realistic average wood growth of $4.4 \mathrm{~m}^{3}$ $\mathrm{ha}^{-1} \mathrm{yr}^{-1}$ or $1055 \mathrm{~kg} \mathrm{Cha}^{-1} \mathrm{yr}^{-1}$ (bark included).

From this the total dry matter production and the litter production of forests can be derived on the basis of a dry matter partitioning. For the forests all over the world the partitioning of dry matter has been established (Cannell, 1982). Based on such data for deciduous and coniferous forests in the Netherlands, Belgium, Ger- 
Table 4. Dry matter partitioning of growth in an 'average' forest in the Netherlands. Based on data of Cannell (1982).

\begin{tabular}{|c|c|c|c|c|c|c|c|}
\hline \multirow[t]{3}{*}{$\begin{array}{l}\text { Growth above } \\
\text { ground }\end{array}$} & $80 \%$ & growth & $53 \%$ & wood growth & $42.4 \%$ & $\begin{array}{l}\text { trunk and large } \\
\text { branches } \\
\text { bark }\end{array}$ & $\begin{array}{r}37.1 \% \\
5.3 \%\end{array}$ \\
\hline & & & & $\begin{array}{l}\text { remaining } \\
\text { growth }\end{array}$ & $10.6 \%$ & $\begin{array}{l}\text { leaves and } \\
\text { needles } \\
\text { small branches }\end{array}$ & $\begin{array}{l}3.0 \% \\
7.6 \%\end{array}$ \\
\hline & & litter fall & $27 \%$ & $\begin{array}{l}\text { fine litter } \\
\text { branches }\end{array}$ & $\begin{aligned} 23 & \% \\
4 & \%\end{aligned}$ & & \\
\hline $\begin{array}{l}\text { Growth below } \\
\text { ground }\end{array}$ & $20 \%$ & $\begin{array}{l}\text { stump and big } \\
\text { fine one- } \\
\text { year roots }\end{array}$ & $10 \%$ & roots & $10 \%$ & & \\
\hline $\begin{array}{l}\text { Total dry matter } \\
\text { production }\end{array}$ & $100 \%$ & & & & & & \\
\hline
\end{tabular}

many and Denmark, a dry matter partitioning has been composed for an 'average' Dutch forest (Table 4). Roughly $80 \%$ of the total dry matter production is used for above ground growth, of which two third contributes to the growth of trunks and foliage. The remainder is litter that annually falls down. After trees are cut, the smaller branches and foliage are left in the forest and the harvested wood is removed. This is about $80 \%$ of the total tree (bark included). There can be large differences in dry matter partitioning between coniferous and deciduous forests, and between old and young forests. However, for an area with one third deciduous forest and two third coniferous forest and with an average tree age of about 35 years, being the average situation in Dutch forests, application of this dry matter partitioning results in reasonable estimates for total dry matter and litter production.

From the average wood growth of $1055 \mathrm{~kg} \mathrm{C} \mathrm{ha}^{-1} \mathrm{yr}^{-1}$ and the dry matter partitioning (Table 4) a total dry matter production of $2490 \mathrm{~kg} \mathrm{C} \mathrm{ha}^{-1} \mathrm{yr}^{-1}$, a wood growth rate with foliage included of $1320 \mathrm{~kg} \mathrm{Cha}^{-1} \mathrm{yr}^{-1}$ and a litter fall (branches included) and a stump and root growth rate of $1170 \mathrm{~kg} \mathrm{Cha}^{-1} \mathrm{yr}^{-1}$ together are derived (Figure 1c). From the amount of harvested wood of $785 \mathrm{~kg} \mathrm{Cha}^{-1} \mathrm{yr}^{-1}$ the total weight of harvested trees and their fine branches and foliages that remain in the forest, are calculated to be 980 and $195 \mathrm{~kg} \mathrm{C} \mathrm{ha}^{-1} \mathrm{yr}^{-1}$, respectively. The amount and the growth of stumps and big roots are derived from the amount and growth of the standing wood, in proportion to the dry matter distribution (Table 4: 10/53). The amount of standing wood increases with $(1320-980=) 340 \mathrm{~kg} \mathrm{C} \mathrm{ha}^{-1} \mathrm{yr}^{-1}$ and hence, the amount of stumps and big roots with $65 \mathrm{~kg} \mathrm{Cha}^{-1} \mathrm{yr}^{-1}$. The total amount of stumps is estimated at $4270 \mathrm{~kg} \mathrm{Cha}^{-1}$.

Organic material that remains in the forest, is composed of remainder after tree cutting (195 kg C ha $\mathrm{yr}^{-1}$ ), litter fall (branches included) and dead stumps and roots $\left(1170-65=1105 \mathrm{~kg} \mathrm{C} \mathrm{ha}^{-1} \mathrm{yr}^{-1}\right)$ (Figure 1c). Two third of this amount accu- 
mulates in the litter layer. It consists for $70 \%$ of fine organic material with a residence time varying between 1 year for deciduous litter to 3 years for coniferous litter and for $30 \%$ of coarse organic material with a residence time of about 8 years. This results in a total accumulation in the litter layer of $3290 \mathrm{~kg} \mathrm{C} \mathrm{ha}^{-1}$ (Figure 1c).

The amount of organic material that annually is incorporated into the soil, is equal to $1300 \mathrm{~kg} \mathrm{Cha}^{-1}$. After one year $80 \%$ of the initially incorporated amount is not yet decomposed (Table 1) and the effective supply of organic material becomes $1040 \mathrm{~kg} \mathrm{C} \mathrm{ha}^{-1} \mathrm{yr}^{-1}$. At a state of equilibrium this yields a pool of soil organic matter of $52000 \mathrm{~kg} \mathrm{C} \mathrm{ha}^{-1}$. The relative decomposition rate used is identical to that in arable land for the same reasons as mentioned previously for grassland.

The forest area in the Netherlands has increased from 299000 ha in 1964-1968 to 334000 ha in 1980-1983. A further increase in forest area is to be expected, particularly on arable land that has become superfluous. Generally mentioned objectives for planting forests are a reduction in net $\mathrm{CO}_{2}$ emission by way of carbon storage and a reduction in timber import. If arable land is converted into forest, the pool of soil organic matter increases considerably (Figure 1), mainly due to the large humification coefficient of forest litter. If the effect of manuring on the organic matter pool of arable land is taken into account too, which will be treated in the following, the increase in soil organic matter due to afforestation is actually nil. Therefore, new forests will only fix carbon through their growing volume standing wood and stumps. The effective rate of carbon fixation is derived to be about $36 \%$ of the annual growth of wood and stumps of $(1320+250=) 1570 \mathrm{~kg} \mathrm{Cha}^{-1} \mathrm{yr}^{-1}$, i.e. $565 \mathrm{~kg} \mathrm{C}$ $\mathrm{ha}^{-1} \mathrm{yr}^{-1}$, if it is taken into account that forests will be thinned out and that of the total wood production during one forest rotation only half the amount will on an average be present.

\section{Manuring}

The total manure production has almost been doubled since 1950, and since 1980 it is about constant (Table 5), as over these last years a decreasing manure production by cattle is just compensated by an increasing production in the pig- and poultry-

Table 5. Total manure production in the Netherlands and manure production averaged over the total area cultivated land at present ${ }^{1}$, the resulting effective supply of organic material and carbon pool at a state of equilibrium.

\begin{tabular}{lllll}
\hline Year & $\begin{array}{l}\text { Total manure } \\
\text { production } \\
\left(10^{6} \mathrm{~kg} \mathrm{C} \mathrm{yr}^{-1}\right)\end{array}$ & $\begin{array}{l}\text { Average manure } \\
\text { production } \\
\left(\mathrm{kg} \mathrm{C} \mathrm{ha}^{-1} \mathrm{yr}^{-1}\right)\end{array}$ & $\begin{array}{l}\text { Effective supply } \\
\text { of organic material } \\
\left(\mathrm{kg} \mathrm{C} \mathrm{ha}^{-1} \mathrm{yr}^{-1}\right)\end{array}$ & $\begin{array}{l}\text { Carbon pool } \\
\left(\mathrm{kg} \mathrm{C} \mathrm{ha}^{-1}\right)\end{array}$ \\
1987 & 2685 & 1333 & 773 & 38660 \\
1980 & 2643 & 1312 & 761 & 38060 \\
1970 & 2058 & 1022 & 593 & 29630 \\
1950 & 1510 & 750 & 435 & 21740 \\
\hline
\end{tabular}

${ }^{1}$ Area of cultivated land in the Netherlands was in 1987 equal to 2014000 ha. 
farming. The increase in livestock size and the resulting increase in production of meat, dairy and manure has been made possible by the strongly enlarged use of concentrates, being imported to a large extent, and by the increased production of roughage.

If it is assumed that manure is spread uniformly over the total area of cultivated land in 1987, the average application becomes $1333 \mathrm{~kg} \mathrm{C} \mathrm{ha}^{-1} \mathrm{yr}^{-1}$ for 1987 and 750 $\mathrm{kg} \mathrm{C} \mathrm{ha}^{-1} \mathrm{yr}^{-1}$ for 1950 . As after one year $58 \%$ of the initially applied amount is not yet decomposed (Table 1), the effective supplies in 1987 and 1950 become 773 and $435 \mathrm{~kg} \mathrm{C} \mathrm{ha}^{-1} \mathrm{yr}^{-1}$, respectively. At a state of equilibrium they yield pools of soil organic matter of 38660 and $21740 \mathrm{~kg} \mathrm{C} \mathrm{ha}^{-1}$, respectively (Table 5). These pools should be considered as additional to the pools that have already been calculated on the basis of stubble and root residues (Figure 1). If the manure production at the moment is about maximum and remains at that level in times to come, the average amount of organic matter in Dutch soils will increase with $16920 \mathrm{~kg} \mathrm{C} \mathrm{ha}^{-1}$ from 1950 till the moment that a new state of equilibrium is largely attained, i.e. in about 100 years.

\section{Conclusion}

In the land use systems of the Netherlands a number of changes has occurred that affect the sizes of the carbon pools. The most important changes are a decreasing area cultivated with small grains, an increasing area cultivated with fodder maize, a decrease in grassland area, an increase in forest area and an increasing manure production. For each of these changes their effect on the carbon pool sizes has been calculated per hectare and for the Netherlands in total (Table 6).

Both the changed crop rotation on arable land and the decreasing grassland area cause a decrease in carbon pool size (Table 6). This decrease is more than compensated by the increase in manure production. However, this increase results mainly from importing an increasing amount of arable products for the live stock. In that case carbon is concentrated in the Netherlands and considered on a global scale, it is not additionally fixed. The increase in forest area is rather small and results in a

Table 6. Changes in carbon pool sizes by changes in land use.

\begin{tabular}{|c|c|c|c|}
\hline & $\begin{array}{l}\text { Change in pool size } \\
\left(\mathrm{kg} \mathrm{Cha}^{-1} \mathrm{yr}^{-1}\right)\end{array}$ & $\begin{array}{l}\text { Area } \\
\left(10^{3} \mathrm{ha}\right)\end{array}$ & $\begin{array}{l}\text { Total change in pool } \\
\text { size in the Netherlands } \\
\left(10^{6} \mathrm{~kg} \mathrm{C} \mathrm{yr}^{-1}\right)\end{array}$ \\
\hline $\begin{array}{l}\text { Changed crop rotation } \\
\text { Increasing manure }\end{array}$ & -132 & 787 & -104 \\
\hline $\begin{array}{l}\text { production } \\
\text { Converting arable }\end{array}$ & +169 & 2014 & +340 \\
\hline land in grassland & +410 & -200 & -82 \\
\hline $\begin{array}{l}\text { Converting arable } \\
\text { land in forest } \\
\text { Doubling forest area }\end{array}$ & $\begin{array}{l}+565 \\
+565\end{array}$ & $\begin{array}{l}+35 \\
+300\end{array}$ & $\begin{array}{l}+20 \\
+170\end{array}$ \\
\hline
\end{tabular}


limited increase in carbon pool size. That cannot compensate for the carbon losses by the other changes in land use.

Extension of the forest area on redundant arable land is often mentioned as a way to fix carbon temporarily in the growing trees and to reduce the rise of atmospheric $\mathrm{CO}_{2}$. Therefore, it is calculated how effective almost doubling the forest area in the Netherlands would be (Table 6). From these calculations it is derived that doubling the forest area would just be sufficient to offset carbon losses by the other changes in land use and that it would not result in additional carbon fixation.

The applied equilibrium approach can be considered as a simple tool to derive average carbon pool sizes in soils, if the supply of organic material is known. If this supply is changed, the new carbon pool at equilibrium and the rate of change in pool size can be calculated. This approach is suited to analyse effects of changing land use on the carbon fixation in soils, and is particularly useful for large-scale studies. For example, it can be used to study the effects on net $\mathrm{CO}_{2}$ emission of a high rate of deforestation in the tropics and of a transfer of climate zones with their characteristic vegetation due to the expected global warming.

\section{Acknowledgement}

This article is based on a study on the non-fossil carbon flows and carbon pools in land use systems in the Netherlands that has been financed by the Ministry of Housing, Physical planning and Environment.

Dr. J. Goudriaan is gratefully acknowledged for his valuable suggestions during the study and comments on the manuscript.

\section{References}

Bouwman, A. F., 1990. Soils and the greenhouse effect. John Wiley and Sons, Chichester, New York, $575 \mathrm{pp}$.

Cannell, M. G. R., 1982. World forest biomass and primary production data. Academic Press, London, New York, 389 pp.

FAO, 1988. Yearbook of forest products 1986 . FAO, Rome, $348 \mathrm{pp}$.

Hoogerkamp, M., 1973. Accumulation of organic matter under grassland and its effects on grassland and on arable crops. Agricultural Research Reports 806, Pudoc, Wageningen, Netherlands, 24 pp.

Hove, J. van, 1969. Variation in the organic matter content and the $\mathrm{C} / \mathrm{N}$ ratio in the surface layers of the soils of low and central Belgium. Ph. D. thesis, University of Gent, Belgium, $291 \mathrm{pp}$.

Janssen, B. H., 1984. A simple method for calculating decomposition and accumulation of 'young' soil organic matter. Plant and Soil 76: 297-304.

Janssen, B. H., F. C. T. Guiking, D. van der Eijk, E. M. A. Smaling, J. Wolf \& H. van Reuler, 1990. A system for quantitative evaluation of the fertility of tropical soils (QUEFTS). Geoderma 46: 299-318.

Jenkinson, D. S., 1988. Soil organic matter and its dynamics. In: A. Wild (Ed.), Russell's soil conditions and plant growth, p. 564-607. Longman Scientific and Technical, Harlow, Essex.

Jenkinson, D. S. \& A. Ayanaba, 1977. Decomposition of carbon-14 labeled plant material under tropical conditions. Soil Science Society of America Journal 41: 912-915.

Kolenbrander, G. J., 1974. Efficiency of organic manure in increasing soil organic matter content. Transactions 10th International Congress of Soil Science, Moscow, Vol. 2. p. 129-136.

Kortleven, J., 1963. Quantitative aspects of accumulation and decomposition of soil organic matter. Agricultural Research Reports 69.1, Pudoc, Wageningen, Netherlands, 109 pp.

Minderman, G., 1968. Addition, decomposition and accumulation of organic matter in forests. Journal of Ecology 56: 355-362. 